\title{
Endometriosis of the Abdominal Wall - Clinical, Histopathological and Immunohistochemical Aspects
}

\author{
ANCA MARIA ISTRATE OFITERU1,2,3, SABINA BERCEANU ${ }^{1}$, STEFAN PAITICI ${ }^{4}$, GABRIELA CAMELIA ROSU2,3, LARISA IOVAN ${ }^{1,2,3}$, \\ NICO LETA LOREDANA VOICU 1,2 , DANIEL PIRICI ${ }^{2,5}$ LAURENTIU MOGOANTA ${ }^{2,3}$, RADU VLADAREANU ${ }^{6}$, CLAUDIA MEHEDINTU6*, \\ ELVIRA BRATILA ${ }^{6}$, OVIDIU BRATU ${ }^{6}$, COSTIN BERCEANU ${ }^{1 *}$ \\ ¿University of Medicine and Pharmacy of Craiova, Department of Obstetrics and Gynecology, 2 Petru Rares, 200349, Craiova, \\ Romania \\ 2University of Medicine and Pharmacy of Craiova Research Center for Microscopic Morphology and Immunology, 2 PetruRares \\ Str., 200349, Romania \\ ${ }^{3}$ University of Medicine and Pharmacy of Craiova, Department of Histology, 2 PetruRares Str., 200349, Romania \\ ${ }^{4}$ University of Medicine and Pharmacy of Craiova, Department of General Surgery, 2 PetruRares Str., 200349, Craiova, Romania \\ ${ }^{5}$ University of Medicine and Pharmacy of Craiova, Department of Metodology, 2 PetruRares Str., 200349, Craiova, Romania \\ ${ }^{6}$ Carol Davila University of Medicine and Pharmacy, 8 Eroii Sanitari Blvd., 050474, Bucharest, Romania
}

\begin{abstract}
Endometriosis is a benign gynecological pathology that mostly affects the organs of the pelvis,but also organs located at a distance maybe affected. Tissue immunohistochemically identified as ectopic endometrium may undergo certain structural and functional changes that may lead to preneoplastic alterations (hyperplasia, dysplasia) in normal cellswhich can evolve to neoplasia. Clinical, genetic, metabolic conditions and local factors may influence degeneration of a benign pathology into a malignant pathology. Endometriosis of the abdominal wall is more frequently encountered, as the number of casarean section has increased. Endometriomas surrounding tissue has a directimpact on the structure of the cells that form the mass. By remodeling cellular morphology, corroborated with the hormonal factors action and the inflammatory response ( via lymphocyte cell secretion), the cell cycle is altered and antiapoptotic activity may be promoted. Immune system via lymphocyte cell secretion, the pressure exerted on the tumor area by surrounding tissueswith its size change, conditioned by the fluctuation of hormonal factors, act directly on the cellular structure and can increase anti-apoptotic action and decrease cell cycle regulation. The presence of endometriomas is identified by the positivity of immunohistochemical reactions for estrogen receptors $(E R)$, progesteron receptors $(P R)$, Cytokeratin $7(C K 7)$ for endometrial tissue. Negative reaction at Cytokeratin 20 (CK20) shows that the studied area is not a metastasis of a digestive tumor. The presence of abundant inflammatory, peritumoral cells markedwith anti-CD68 / Tryptase for macrophages / mast cells demonstrates the involvement of the inflammatory system in the structural and functional modification of endometrial cells.The pronounced cell division was demonstrated by intense reaction with the anti-Ki67 antibody. The signigicant anti-apoptotic action of the endometrial tissue is shown by the positivity of anti-B cell Lymphoma 2 (BCL2) / anti-Phosphatase and tensin homolog (PTEN) / anti-p53 antibodies.
\end{abstract}

Keywords: endometriosis, progesterone receptor, estrogen receptor, Bcl-2, PTEN

Ectopic endometrial implantscan be presentin the pelvic organs: ovaries, uterine ligaments, rectovaginal septum, peritoneum and extra pelvic structures like kidneys, lymph nodes, pleura, lungs, brain and abdominal wall [1,2].

Patients experience period-related pain.Tumor's size was significantly bigger before menstruation. This increaseamplifies the symptoms.In the time between menstruations, these patients were asymptomatic and they did not report any vaginal bleeding.

In areas of focus, the presence of a large number of ER and PR was demonstrated, in addition toan increasing hormone secretion, causing an abnormal activity of steroidogenesis $[3,4]$.

The aims of this study were: to identifythe presence of ectopic endometrial tissue, to evaluate the inflammatory reaction around it and to observe the preneoplastic (hyperplasic) transformation of the areas of interest.

\section{Experimental part}

This retrospective study included a total of 20 patients, who were admitted in the Obstetrics-Gynecology II Clinic of the Craiova County Emergency Clinical Hospital, between 2010-2018. The endometriosis diagnosis was based on thepatients' history (all of them had underwentc-section), their intense symptoms and the presence of endometriomas in their ultrasound examination. The final diagnosis was established after the excision and the biopsy of the endometriomas was performed and the histopathological results were available. All the patients included in the study signed the acceptance form (approved by the Ethics Commission of the University of Medicine and Pharmacy of Craiova) for inclusion in the study after having been provided in writing and verbally with all necessary information. The subjects were divided into two groups: one group formed of 10 patients diagnosed with post-cesarean section abdominal wall endometriosis without preneoplastic alterations and another one composed of 10 patients affected byatypical endometriosis - hyperplasic glands.

Patients' age ranged from 18 to 57 years old and the premalignant condition was diagnosed on older subjects, compared to the benign endometriosis(Chart 1).

Following excision surgery, the tissue was fixed in 10\% formalin solution and embedded in paraffin wax as it follows: after fixation, the tissue was washed in tap water for one hour to remove the fixation solution. Then the tissue was immersed into successive alcohol baths $70,90,96 \%$, for one hour each and it was left overnight in absolute 
alcohol bath in order to remove tissue's water. The next day, the samples were passed successively through 3 xylene baths, one hour each, and then introduced into the molten paraffin, at $56^{\circ} \mathrm{C}$, placed in the thermostat, until the next day, so the paraffin penetratesthe tissue. On the third day, the solid paraffin block was made and it was cut using the HMB350 microtome equipped with a waterbased transfer system (STS microM). The $5 \mu \mathrm{m}$ sections were applied on clear glass slides and poly-L-lysine coated slides for the histological and immunohistochemical study. For the Haematoxylin and Eosin staining, the sections weredeparaffinized in xylene for 45 minutes, hydrated in successive alcohol baths with decreasing concentration: $100,96,90,70 \%$, three distilled water baths, of 5 min each, then the nucleiwere stained with the Mayer's Haematoxylin solution (crystallized haematoxylin $1.0 \mathrm{~g}$, distilled water $1000 \mathrm{~mL}$, sodium iodide ( $\mathrm{NalO3}$ ) $0.2 \mathrm{~g}$, aluminum sulphate $50.0 \mathrm{~g}$, citric acid $1 \mathrm{~g}$, chlorohydrate $50 \mathrm{~g}$ ). The sampleskept for $1 \mathrm{~min}$ in this solution and the nuclei were colored in redviolet. To neutralize the solution and stain the nuclei blue, the colored slides were introduced into tap water for a few minutes (the alcaline content from water neutralizes acidity of aluminium haematoxylin to from the blue aluminium haematin complex). Subsequently, the cell cytoplasm and collagen fibers were dyedwith Floxic-Eosin solution (Stock solution Eosin Y: eosin:1g, distilled water $100 \mathrm{~mL}$, alcohol 96\% -300ml. Eosin was dissolved in warm water and, after cooling, alcohol was added; Stock solution Floxin: floxin: $1 \mathrm{~g}$, distilled water $-100 \mathrm{~mL}$, alcohol $96 \%$ $300 \mathrm{~mL}$. To dissolve the floxin, the solution should be warmed up;The Eosin-Floxin Work Solution: Eosin stock $450 \mathrm{~mL}+$ Floxin stock $50 \mathrm{~mL}+$ Glacial Acetic Acid $2 \mathrm{~mL}$ ) for a few minutes.

For the immunohistochemical study, the sections were dewaxed and rehydrated similarly, a 'magic circle' was drawn around the tissue sections using a Dako Pen, a water repelling solution and then the slides were boiled in the microwave oven (650W), while submerged in Citratesolution $\mathrm{pH}=6[5,6]$ (Sodium Citrate $29.4 \mathrm{~g}, \mathrm{HCl} 1 \mathrm{M}$ $29.4 \mathrm{~g}$, distilled water $\mathrm{IL}$, and adjusting the $\mathrm{pH}$ to 6 with $1 \mathrm{M}$ $\mathrm{HCl}$. Furtheron, for the stock solution of Citrate buffer (10x) pH 6 to expose the antigen, we used Citric Acid Monohydrate $21.014 \mathrm{~g}$ anddistilled water $1000 \mathrm{~mL}$, following the $\mathrm{pH}$ adjustment with $\mathrm{NaOH}$ and $1: 10$ dilution with distilled water at the time of use) / EDTA pH=9 (Tris-EDTA: we used ethylenediaminetetraacetic acid $0.372 \mathrm{~g}$, distilled water $1000 \mathrm{~mL}$ and adjusting the $\mathrm{pH}$ to 9 with $\mathrm{NaOH}$ and $\mathrm{HCl}$ ) 7 cycles $\times 3$ min for antigen unmasking. After cooling, the slides were washed in 3 distilled water baths for $5 \mathrm{~min}$ each.Afterwards the blocking of nonspecific sites (endogenous peroxidase) was achieved using diluted Perhidrol solution ( $2 \mathrm{~mL}$ of $30 \%$ perhydrol, $100 \mathrm{~mL}$ distilled water) for $30 \mathrm{~min}$, and washing the slides in 2 distilled water baths for 5 min each in Phosphate-buffered saline (PBS) solution ( $\mathrm{NaCl} 0.12 \mathrm{M}$ - 13.92g, $\mathrm{NaH}_{2} \mathrm{PO} \cdot 2 \mathrm{H}_{2} \mathrm{O} 0.01 \mathrm{M}$ - 3.12g, $\mathrm{K}_{2} \mathrm{HPO}$ 0.04M -13.92g, distilled $\mathrm{H}_{2} \mathrm{O}^{2} 20 \mathrm{O}^{2} \mathrm{~mL}$ ) [7]. Subsequently, the slideswere sunkin 3\% skimmed milk powder solution $3 \mathrm{~g}$ powdered milk $+100 \mathrm{~mL}$ PBS) for 30 min. The last step of the first day is the addition of the primary antibody to the sections (table 1 ) and leaving the slides in a wet container for $18 \mathrm{~h}$ at a temperature of $-4^{\circ}$ C.The following day the cold slides were brought at room temperature, washed in PBS for 5 min 3 times,then the secondary antibody was applied(Mouse/Rabbit IgG Antibody, VC002-025, R\&D Systems, VisUCyte HRP Polymer), which remained for $1 \mathrm{~h}$, then they were developed with 3, 3'-Diaminobenzidine (DAB) (Dako). The reaction is blocked in PBS, slides arewashed in distilled water, and the nuclei are counterstained using Mayer's Haematoxylin.After that, the sections are dyhidrated with increasing alcohols $(70,90,96,100 \%)$ and then, they are clarified in three xylene baths (15 mineach) and covered withcover glassusing Canada balm.

\begin{tabular}{|c|c|c|c|c|c|c|c|}
\hline $\begin{array}{l}\text { Anti- } \\
\text { body }\end{array}$ & $\begin{array}{l}\text { Manu- } \\
\text { facturer }\end{array}$ & Clone & $\begin{array}{l}\text { Antigenic } \\
\text { exposure }\end{array}$ & $\begin{array}{l}\text { Secondary } \\
\text { antibody }\end{array}$ & Dilution & Labeling & \\
\hline $\begin{array}{l}\text { Anti- } \\
\text { CK7 }\end{array}$ & Dako & $\begin{array}{l}\text { OV-TL } \\
12 / 30\end{array}$ & Citrate, $\mathrm{pH} 6$ & $\begin{array}{l}\text { Monoclonal mouse } \\
\text { anti-human } \\
\text { cytokeratin } 7\end{array}$ & $1: 50$ & Glandular epithelia & \\
\hline $\begin{array}{l}\text { Anti- } \\
\text { CK20 }\end{array}$ & Dako & Ks20.8 & Citrate, $\mathrm{pH} 6$ & $\begin{array}{l}\text { Monoclonal mouse } \\
\text { anti-human } \\
\text { cytokeratin } 20\end{array}$ & $1: 25$ & $\begin{array}{l}\text { Cellular protein of } \\
\text { mature enterocytes } \\
\text { and goblet cells }\end{array}$ & \\
\hline Anti-ER & Dako & $1 \mathrm{D5}$ & EDTA, pH9 & $\begin{array}{l}\text { Monoclonal mouse } \\
\text { anti-human estrogen } \\
\text { receptor alfa }\end{array}$ & $1: 50$ & Estrogen receptors $\alpha$ & Table 1 \\
\hline Anti-PR & Dako & PgR 636 & EDTA, pH9 & $\begin{array}{l}\text { Monoclonal mouse } \\
\text { anti-human } \\
\text { progesterone } \\
\text { receptor PR }\end{array}$ & $1: 50$ & $\begin{array}{l}\text { Progesterone } \\
\text { receptors }\end{array}$ & $\begin{array}{l}\text { IUNOHISTOCHEMICAL } \\
\text { PANEL OF } \\
\text { ANTIBODIES }\end{array}$ \\
\hline Anti-p53 & Dako & DO-7 & EDTA, pH9 & $\begin{array}{l}\text { Monoclonal } \\
\text { mouseanti-human } \\
\text { p53 protein }\end{array}$ & $1: 50$ & Nuclear marker & \\
\hline $\begin{array}{l}\text { Anti- } \\
B C L 2\end{array}$ & Dako & 124 & EDTA, pH9 & $\begin{array}{ll}\text { Monoclonal mouse } \\
\text { anti-human } \\
\text { oncoprotein }\end{array}$ & $1: 50$ & B-cell lymphoma 2 & \\
\hline $\begin{array}{l}\text { Anti- } \\
\text { PTEN }\end{array}$ & Abcam & $a b 31392$ & Citrate, $\mathrm{pH} 6$ & Polyclonal Rabbit & $1: 50$ & $\begin{array}{l}\text { Tumour suppressor } \\
\text { gene }\end{array}$ & \\
\hline $\begin{array}{l}\text { Anti- } \\
\text { CD68 }\end{array}$ & Dako & $\mathrm{KP1}$ & Citrate, pH6 & $\begin{array}{l}\text { Monoclonal mouse } \\
\text { anti-human } \\
\text { CD68 }\end{array}$ & $1: 100$ & Macrophages & \\
\hline $\begin{array}{l}\text { Anti- } \\
\text { Tryptase }\end{array}$ & Dako & AA1 & Citrate, $\mathrm{pH} 6$ & $\begin{array}{l}\text { Monoclonal mouse } \\
\text { anti-human } \\
\text { cell tryptase }\end{array}$ & 1500 & Mast Cells & \\
\hline
\end{tabular}


At the end, the sections were imaged utilisiong a Nikon Eclipse 55i microscope equipped with a 5MP CCD color cooled camera and the Image ProPlus 7 analysis software (Media Cybernetics).All images were stored as uncompresed tiff files, and the DAB signal on each immunohistochemistry slide was quantified as the number of units (cells). The values were then averaged per patient and then the data were compared utilising a Student's $t$ test. $P$ values $<0.05$ were deemed significant.

\section{Results and discussions}

The ageof the women included in the study are between 18 and 57 years old and it was noticed that precancerous cellular changes (endometrial hyperplasia) occur with a higher frequency in elderlypatients(Chart.1)

All patients complained about chronic pelvic pain.

Through histochemistry we established thediagnosis of endometriosis. Using classic histological Haematoxylin Eosin staining of the tissue sample we observe the simple columnar tissue, the basal located nuclei, and the cytogenetic chorionplaced around the endometrial glands (fig 1.)

Immunohistochemical staining with anti-ER and antiPR antibodies facilitated the identification of the abundance of hormone receptors, which demonstrates the strong involvement of estrogen and progesterone in the evolution of endometriomas (fig 2,3).

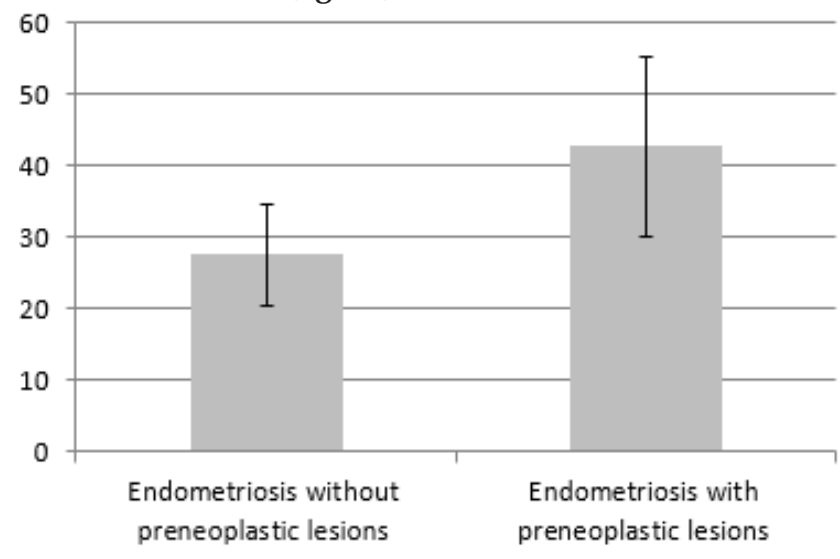

Chart.1Age of diagnosis of endometriosis

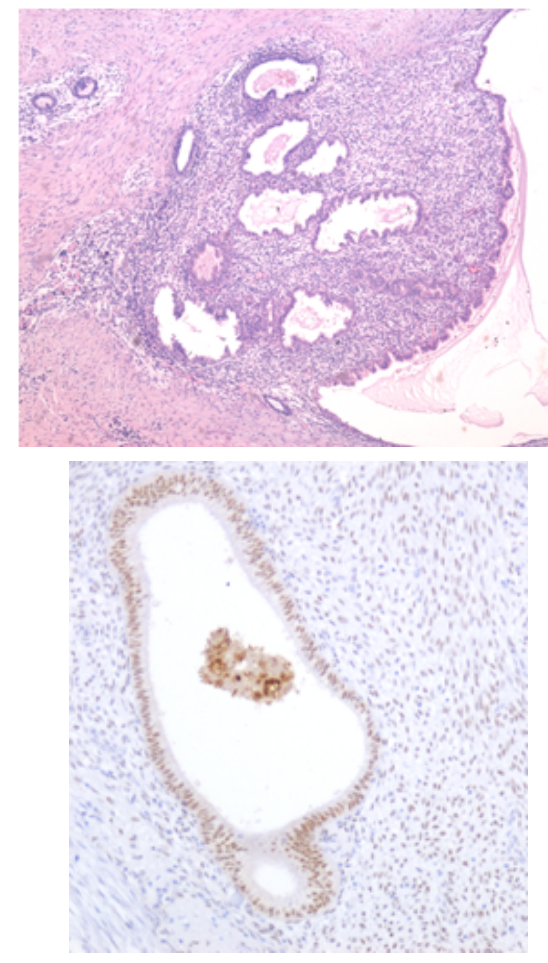

Fig. 2. Anti-ER antibody immunostaining, 200x. Positive reaction to $\mathrm{ER}$ is observed in the epithelia and lamina propria.

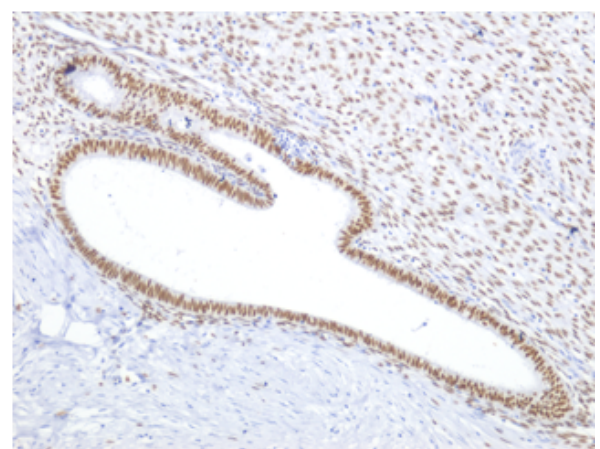

Fig. 3. Anti-PR antibody immunostaining, 200x. Positive reaction to PR is observedin the epithelia and lamina propria

The firstmalignant transformation of endometriosis was described in 1925 by Sampson [7], and the prevalence of this transformation is $0.7-1.6 \%$ [8]. The most common malignant tumor types are: clear cell carcinoma, endometrial carcinoma, various types of endometrial stromalsarcomas, Mulelerian tumors, or borderline tumors and benign tumors [9].

Recent studies have suggested that some genetic mutations at the ER, $\mathrm{p} 53$ or BCL2 level in this phenomenon may be involved [ 10-12].

ER is part of a group of intracellular proteins. These receptors are activated by the estrogenic hormone (17 $\beta$ estradiol) [13]. After activation, the ERs are translocated into nuclei and sets the DNA to regulate the activity of several genes (transcription factor of the DNA) [14]. Ero that is found in the endometrium, mammary carcinoma cells, ovarian stromal cells and in the hypothalamus [15]. $E R \alpha$ se are found in the endometrium, mammary carcinoma cells,, ovarian stromal cells and in the hypotalamus [15].In males, $E R \alpha$ is present in the epithelium of the eferent ducts [16].

PRs are part of the nuclear receptor subfamily 3rd and are activated by the progesterone hormone. PRs are encoded by the PGR gene on chromosome 11q22 [17, 18].

By immunolabelingwith anti-CK 7 and anti-CK20 markers, we were able to differentiate endometrial glands from other structures such as an adenocarcinoma's metastasis originating in the digestive tract.

All factors involved in the etiopathogenesis of endometriosis induce cellularalterations that may promote a malignant transformation of the ectopic endometrial tissue. Thus normal ectopic cells become hyperplasic cells, that may also evolve into dysplastic cells and subsequently transform into neoplastic cells (Chart 2)

CK7 is a protein encoded by the KRT7 gene [19-20], of type II. It is particularly expressed in the epithelium of cavitary internal organs, glandular ducts and blood vessels. The gene coding type II CK is located on chromosome 12q12-q13. These may have other locations, but not all have been fully described.CK7 is expressedby glandular and transient epithelia. It is also found in neoplastic cells, which is why immunohistochemistry differentiates transitional cell carcinomas from ovarian cells. It is used in conjunction with Cytokeratin 20 (CK20) for the differential diagnostic [21] (fig 4, 5).

$\mathrm{BCl}-2$ is part of the $\mathrm{BCl}-2$ family of regulatory proteins, which modulate cell apoptosis by either inducing or inhibiting it [22, 23]. Bcl-2 is located on the outer membrane of the mitochondria and plays an important role in regulating the dynamics of the mitochondrial enzymes. Genetic changes of $\mathrm{BCl}-2$, by unbalancing cell death and 


\section{$(1)$}

Dysplasia

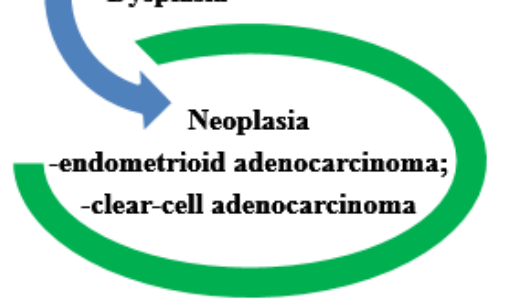

Chart 2. Endometrial cells changes.

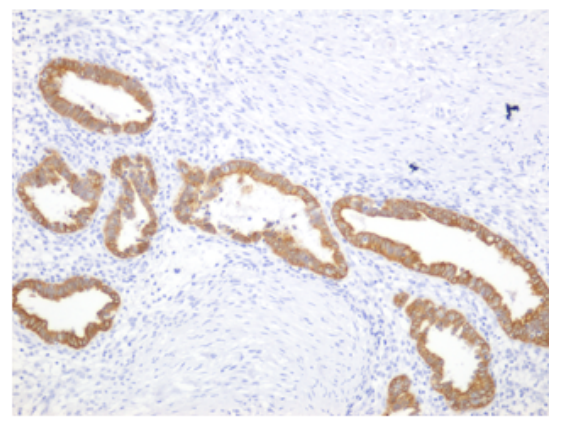

Fig. 4. Anti-CK7 antibody immunostaining, 200x. Intense signal can be observed in the epithelia.

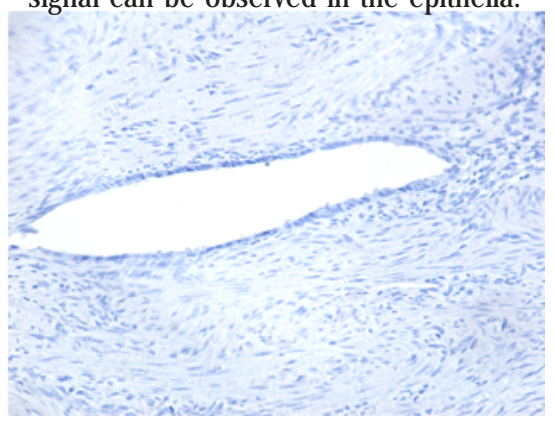

Fig. 5. Anti-CK2 antibody immunostaining, 200x. Negative reaction of the endometrial glands is illustrated

cell growth,are associated with various malignant diseases such as prostate cancer, breast cancer, chronic lym phocytic leukemia, lung cancer.Positive immunostaining with the anti-Bcl-2 antibody reveals marked ectopic endometrial cells, which may influence their transformation into hyperplastic, dysplastic and subsequently neoplastic cells. Using the anti-B-cell lymphoma 2 (BCL2) antibody, we demonstrated the involvement of an anti-apoptotic protein that plays an important role in regulating cell death (fig. 6).

PTEN is a human protein encoded by the PTEN gene [24], and its mutations are linkedto the development of multiple cancers.

PTEN acts as a tumor suppressor gene via a phosphatase protein product. Normally, it blocks the cells' cycle so that they will not grow and will not divide too fast [25]. PTEN gene's mutations may influences the cell cycle, which leads to an accelerated division. During tumor's growth, PTEN mutations or deletions are produced by enzymatic inactivation, thus increasing cell proliferation and decreasing the rate of apoptosis. It is frequently inactivated in endometrial cancer, prostate cancer and it is reduced in many other cancers. The anti-Phosphatase and tensin homolog antibody (PTEN) marks a protein encoded by the PTEN gene (fig. 7). In conclusion, PTEN mutations cause a predisposition to malignancy.

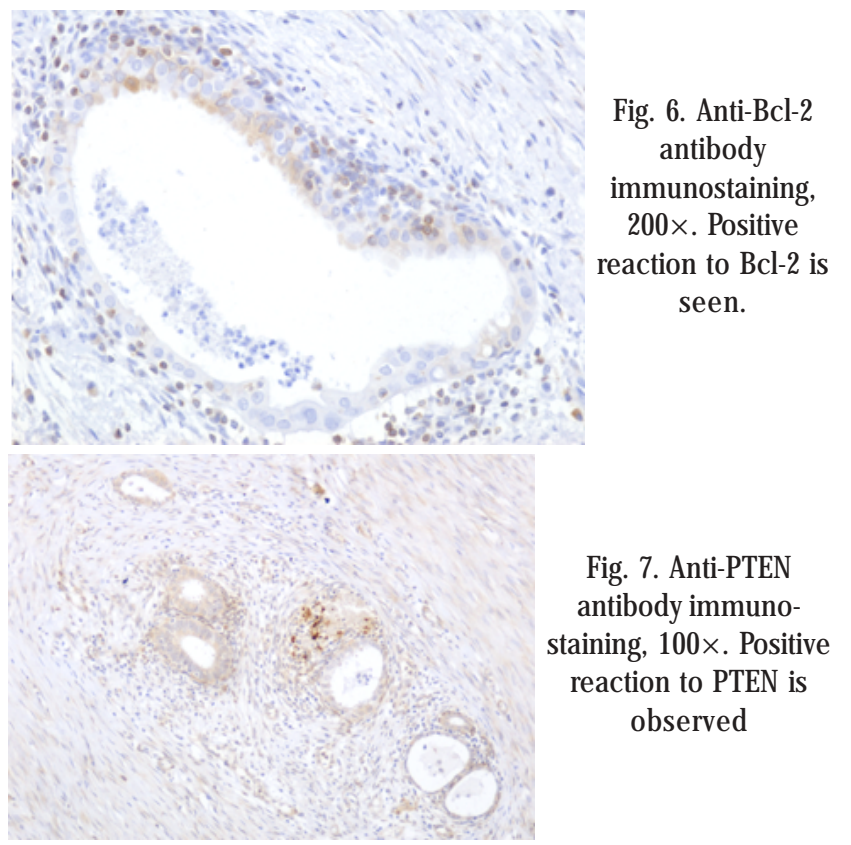

Tryptase is produced by the mast cells and is found in the secretion granules. It is associatedwith the allergic reaction and it is thought to act like fibroblasts. Some genetic mutations resulting from FIP1L1-PDGFRA fusion may be connectedto the neoplastic transformation[26].By immunohistochemical staining using the anti-Tryptase antibody, we illustratedthe presence of many mast cells in the vecinity of the endometriomas, unlike areas situates away from the ectopic endometrial tissue, which were far less populated with mast cells. These cells are closely related with the immune reaction of the endometriomas' surrounding tissue.

CD68 is a protein specific to circulating monocytes and tissue-macrophages (microglia, Kuffer cells) [27]. Immunohistochemical staining detects the presence of CD68 + in cytoplasmic granule macrophages.CD68 is used as a marker for the line of macrophages, monocytes, histiocytes, giant cells, Kuffer cells and osteoclasts. Areas surrounding endomitriomas may encounter a significantly higher macrophage count compared to distant areas.

By using anti-Tryptase and anti-CD68 antibodies immunostaining we have demonstrated that there is an intense inflammatory reaction around ectopic endometrial tissueand that

the number of macrophages and mast cells is greatly increased in these areas as opposed to remote areas (fig. 8, 9), (Chart 3, 4).

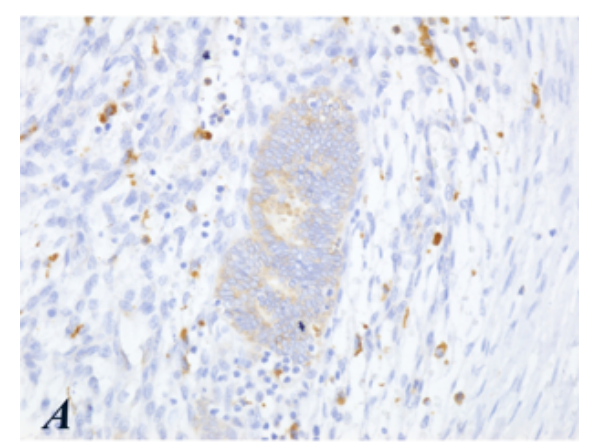

Fig. 8A. Anti-CD68 antibody immunostaining, 200x. Positive reaction to CD68 near the endometriosis is observed 


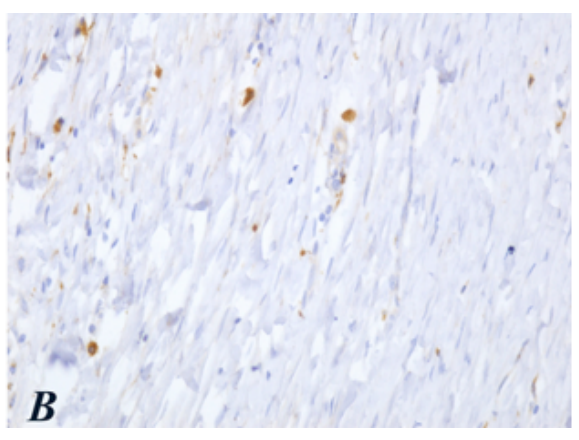

Fig. 8B. Anti-CD68 antibody immunostaining, 200x.Low positive reaction to CD68 away from the endometriosis is observed.
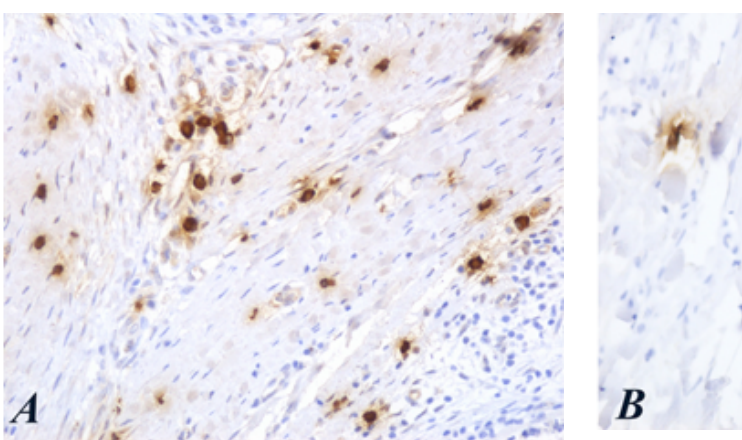

Fig. 9.A. Anti- Tryptase antibody immunostaining, 200x. Positive reaction to Tryptase near the endometriosis is observed; B.Anti- Tryptase antibody immunostaining, 200x. Low positive reaction to Tryptase away from the endometriosis is observed.
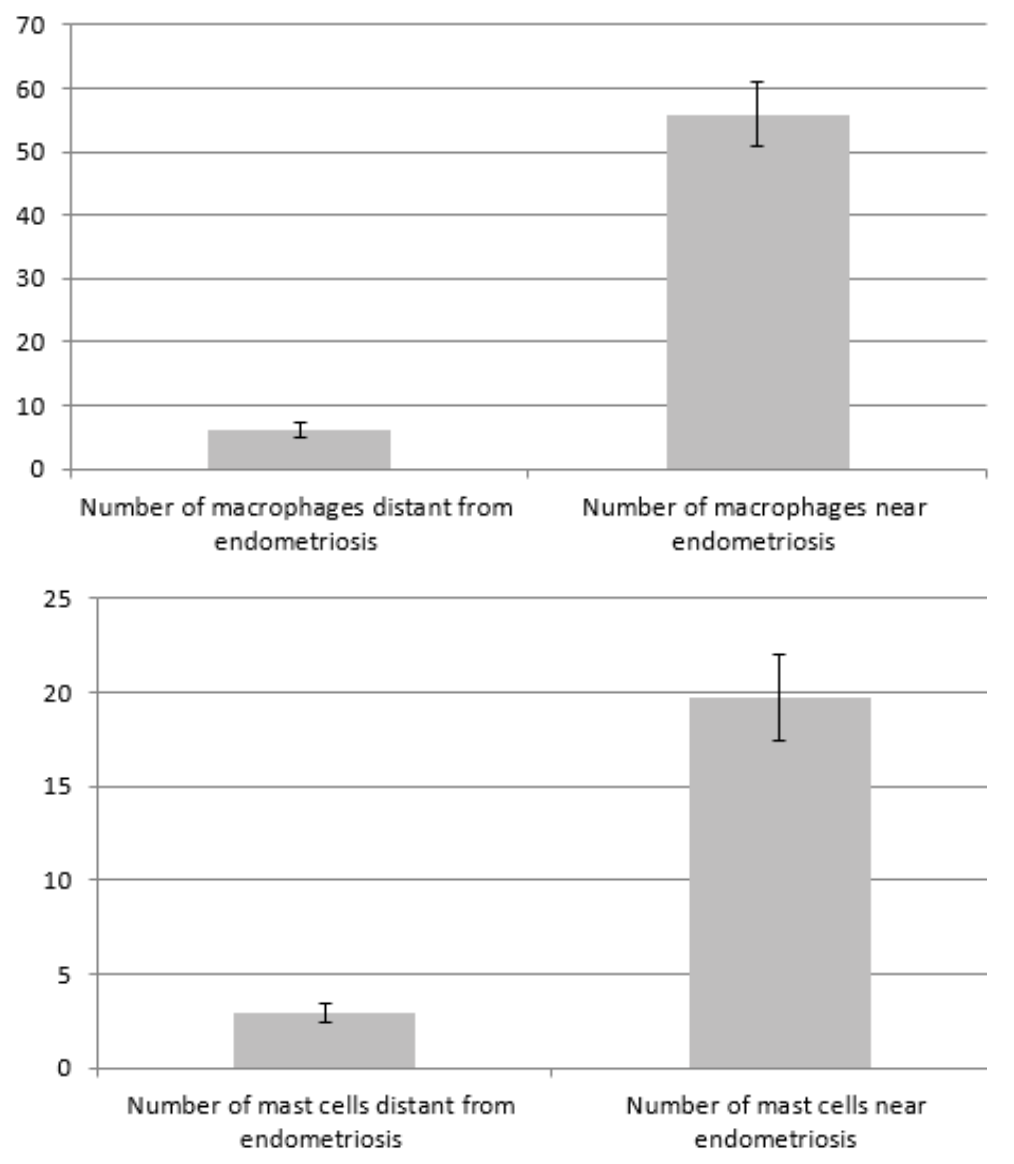

Chart 3. Statistical analysis of the number of macrophages near and away from the endometriosis outbreak. The counting was performed on images obtained with the 200x lens, (statistically significant value: $p<0.001$ ).

Chart 4. Statistical analysis of the number of mast cells near and away from the endometriosis outbreak. The counting was performed on images obtained with the 200x lens, (statistically significant value: $p<0.001$ )

\section{Conclusions}

A multitude of inflammatory, hormonal, and mechanical factors are involved in the occurence and development of endometriosis.

The inflammatory reaction surrounding the ectopic endometrial tissue may contribute to the malignant transformation of it.

Estrogen is involved in the growth and development of glands found in the structure of endometriomas. Decreasing progesterone level creates an unbalance in hormonal status and predisposes to this pathology.

The presence of cellular apoptosis inhibiting genes increases the cell division rate, and the intense immune response can influence the malignant transformation of ectopic endometrial tissue.

The most effective treatment of endometriosis is still surgical removal of the lesions, thus suppressing the pain caused by this pathology and preventingat the same time the malignant transformation of endometriomas.

time required for the DNA repair. The positivityof $p 53$ immunohistochemical reactions suggests the presence of structural and functional cellular lesions leading to malignant transformation of the cells (fig. 10). 


\section{References}

1. MEHEDINTU, C., ANTONOVICI, M., BRINDUSE, L., BRATILA, E., STANCULESCU, R., BERCEANU, C., BRATU, O., PITURU, S., ONOFRIESCU, M., MATASARIU, D.R. Rev.Chim.(Bucharest), 69, no. 3, 2018, p. 581

2. COMANESCU, M., POTECA, A., LAZAROIU, A., SAJIN, M.. Rom J Morphol Embryol 48, no.2, 2007, p. 195-197.

3. BULUN, S.E, LIN, Z, IMIR, G AMIN, S., DEMURA, M., YILMAZ, B., MARTIN, R., UTSUNOMIYA, H., THUNG, S., GURATES, B., TAMURA, M., LANGOI, D., DEB, S. Pharmacol Rev., 57, No. 3, 2005, p. 359.

4.CRISTESCU, C., VELISCU, A., MARINESCU, B., PATRASCU, A., TRASCA, E.T., POP, O.T., Rom J Morphol Embryol., 54, no. 1, 2013, p. 91.

5. CATTORETTI, G., PILERI, S., PARRAVICINI, C., BECKER, M.H., POGGI, S., BIFULCO, C., KEY, G., D'AMATO, L., SABATTINI, E., FEUDALE, E. J Pathol. 171, no 2, 1993, p. 83.

6. SPENCER, L.T., BANCROFT, J.D. TISSUE PROCESSING. IN: BANCROFT, J.D., GAMBLE, M. Churchill Livingstone Elsevier, Sixth Edition, 2008, p. 83

7. SAMPSON, J.A. Arc Surg, 1925, no. 10, p. 1-2.

8. KOBAYASHI, H., SUMIMOTO, K., MONIWA, N., et al.Int J Gynecol Cancer, 2007, no. 17, p. 37-43.

9. ROSAI, J. Female Reproductive System, 10th Edition, Elsevier, 2011, p.1560-70.

10. NEZHAT, F., DATTA, M.S., HANSON, V., PEJ OVIC, T., NEZHAT, C. Fertil Steril, 2008, no. 90, p. 1559-70.

11. NEZHAT F, COHEN C, RAHAMAN J, GRETZ, H., COLE, P., KALIR, T. Cancer, 2002, no. 94, p. 2935-40.

12. KREIZMAN SHEFER, H., PRICOP, J., GOLDMAN, S., ELMALAH, I., SHALEV, E. Diagn Pathol, 2014, no. 9, p.77-85.

13. DAHLMAN-WRIGHT, K., CAVAILLES, V., FUQUA, S., J ORDAN, V., KATZENELLENBOGEN, J., KORACH K., MAGGI, A., MURAMATSU, M., PARKER, MG., GUSTAFSSON, J A. International Union Of Pharmacology, 2006,58(4), p.773-781;

14. LEVIN, E. Molecular Endocrinology, 20055, no.19(8), p.1951-1959; 15. YAGHMAIE, F., SAEED, O., GARAN, S., FREITAG, W., TIMIRAS, P., STERNBERG, H. Neuro Endocrinology Letters, 2005, no. 26(3), p.197203;
16. HESS, R. Reproductive Biology And Endocrinology, 2003, no. 1(52), p.52;

17. MISRAHI, M., ATGER, M., D'AURIOL, L., LOOSFELT, H., MERIEL, C., FRIDLANSKY, F., GUIOCHON-MANTEL, A., GALIBERT, F., MILGROM. Biochemical And Biophysical Research Communications, 1987, no. 143(2), p.740-748;

18. LAW. M., KAO, F., WEI, Q., HARTZ, J., GREENE, G., ZARUCKISCHULZ, T., CONNEELY, O., J ONES, C., PUCK, T., O'MALLEY, B. Proceedings Of The National Academy Of Sciences Of The United States Of America, 1987, no. 84(9), p.2877-1881;

19. ROSENBERG, M., FUCHS, E., LE BEAU, M., EDDY, R., SHOWS, T. Cytogenetics And Cell Genetics, 1991, no.57(1), p. 33-38;

20. SCHWEIZER, J., BOWDEN, P., COULOMBE, P., LANGBEIN, L., LANE, E., MAGIN, T., MALTAIS, L., OMARY, M., PARRY, D., ROGERS, M., WRIGHT, M. The Journal Of Cell Biology, 2006, no. 174(2), p. 169-174; 21. LEONG, ANTHONY, S., COOPER, K., LEONG, F., JOEL, W. Manual Of Diagnostic Cytology (2 Ed.),2003, Greenwich Medical Media, p. 173;

22. TSUJ IMOTO, Y., FINGER, LR., YUNIS, J., NOWELL, P., CROCE, C. Science, 1984, no. 226(4678), p.1097-1099;

23. CLEARY, M., SMITH, S., SKLAR, J. Cell,1986, no.47(1), p.19-28;

24. STECK, P., PERSHOUSE, M., JASSER, S, YUNG, W., LIN, H., LIGON, A., LANGFORD, L., BAUMGARD, M., HATTIER, T., DAVIS, T., FRYE, C., HU, R., SWEDLUND, B., TENG, D., TAVTIGIAN, S. Nature Genetics, 1997, no. 15(4), p.356-362;

25. CHU, E., TARNAWSKI, A. Medical Science Monitor, 2004, no. 10(10), p.Ra235-41;

26. VEGA, F., MEDEIROS, L., BUESO-RAMOS, C., ARBOLEDA, P., MIRANDA, R. American J ournal Of Clinical Pathology, 2015, no. 144(3), p.377-392;

27. HOLNESS, C., SIMMONS, D. Blood, 1993, no. 81(6), p.1607-13; 28. GILBERT, S.F. Developmental Biology, 10th Ed. Sinauer Associates, Inc. Publishers. p. 58.

29. BRATILA, E., IONESCU, O.M., BADIU, D.C., BERCEANU,C., VLADAREANU, S., POP, D.M., MEHEDINTU, C. Rom J Morphol Embryol 57, no.2, 2016, p. 825-829.

$\overline{\text { Manuscript received: } 18.02 .2019}$ 